\title{
Airline passengers' perceptions of service quality: themes in online reviews
}

Ana Brochado (Instituto Universitário de Lisboa (ISCTE-IUL), Dinamia, Lisboa, Portugal)

Paulo Rita (NOVA Information Management School (NOVA IMS), Universidade Nova de Lisboa, Portugal)

Cristina Oliveira (Instituto Universitário de Lisboa (ISCTE-IUL), ISTAR-IUL, Lisboa, Portugal)

Fernando Oliveira (Instituto Universitário de Lisboa (ISCTE-IUL), Lisboa, Portugal)

This is the author accepted manuscript version of the article published by EMERALD as:

Brochado, A., Rita, P., Oliveira, C., \& Oliveira, F. (2019). Airline passengers' perceptions of service quality: themes in online reviews. International Journal of Contemporary Hospitality Management, 31(2), 855-873. https://doi.org/10.1108/IJCHM-09-2017$\underline{0572}$

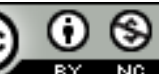

This work is licensed under a Creative Commons Attribution-NonCommercial 4.0 International License. 


\title{
Airline passengers' perceptions of service quality: themes in online reviews
}

\begin{abstract}
Purpose: This study's primary objectives were to identify the main themes shared in online reviews by airline travellers, as well as which of these themes were linked with higher and lower value for money ratings.

Design/methodology/approach: The research used mixed content analyses (i.e. quantitative and qualitative) to examine 1,200 reviews of six airline companies shared by airline travellers in a social media platform.

Findings: The analyses revealed nine themes in descriptions of airline travel experiences. These are the core services during 'flights', 'airport' operations, crew and ground 'staff', ticket 'classes', 'seats', inflight 'services', 'entertainment', overall experiences of 'airlines' and post-purchase recommendations of with which companies to 'fly'. Low value for money ratings are linked with the 'airport' and 'flights' themes.

Originality/value: The results offer useful insights into airline travellers' overall experiences based on social media information and facilitate the identification of the main themes linked with different value for money ratings.
\end{abstract}

Keywords: airline industry, Web reviews, content analysis, value for money, service quality

Article Classification: Research paper

\section{Introduction}

The provision of superior service quality is widely acknowledged as an important source of customer retention and loyalty, which can ultimately lead to superior competitive performance (Zeithaml et al., 1996). Improving the quality of services provided and achieving customer satisfaction is particularly challenging in servicebased industries (Ali et al., 2015). This is true for the airline industry, which includes a quite strong service element (Frost and Kumar, 2000), as airlines provide extremely complex services and products. These involve multiple service encounter stages that can 
influence overall levels of customer satisfaction (Chen and Chang, 2005; Archana and Subha, 2012).

Due to the homogeneity of the main service offered (i.e. moving people and goods from one destination to another) (Frost and Kumar, 2000), airlines achieve differentiation through the provision of better service quality (Gourdin and Kloppenbourg, 1991; O'Connell and Williams, 2005) when competing for customers (Hussain, 2016). Various studies have found evidence that service quality initiatives and customer relationship management have become vital to airlines' ability to gain competitive advantages (Atalik et al., 2009; Nejati et al., 2009) and retain customer patronage (Ostrowski et al., 1993; Park et al., 2004). Thus, airline service quality and its role in the key business strategy of differentiation have assumed greater importance in recent years (Tiernan et al., 2008).

Previous research has shown that service quality is central to airline passengers' satisfaction and that service quality is demanded by both business and leisure class clients (Young et al., 1994). In order to stay competitive, airlines need to identify and prioritise clients' needs and expectations to ensure customer satisfaction (Chang and Yeh, 2002; Nadiri et al., 2008; Nejati et al., 2009). These companies have already developed and improved a variety of services to customers such as ticket reservation and purchase, airport ground service, on-board services, destination services, lostbaggage handling and delayed passenger services (Tsaur et al., 2002).

Researchers have largely employed survey methods to develop and test new instruments to measure service quality in the airline industry (see Li et al. [2017] for a review). However, a few recent studies have highlighted the advantages of analysing usergenerated content on the Internet when studying customers' satisfaction with their travel experiences (Zhang and Cole, 2016). The airline industry is one of the most socially intensive sectors, and social media platforms allow airline companies to conduct twoway communication with their costumers (Liau and Tan, 2014).

Moreover, electronic word of mouth (eWOM) shared by other customers is considered trustworthy by airline passengers. Messner (2017) found that higher value for money ratings shared online in social media platforms are linked with positive recommendations of airlines. Although perceived value for money and service quality have been shown to be linked with customers' positive behavioural intentions, the 
existing literature is still unclear about which service features provide better value for money (Rajaguru, 2016).

Given this research gap, the present study sought to examine the narratives shared online by airline travellers. The two primary objectives of this study were to identify the main themes that describe overall impressions of airline experiences shared online and to identify the themes most closely aligned with higher and lower value for money ratings.

This paper is thus structured as follows. The literature review discusses the concept of service quality, presents the main dimensions of service quality in airline industry services, discusses the concept of value for money and analyses the role of Web content in service quality studies. The methodology section presents the sample, data collection, variables in the data set and mixed content analyses performed on the content of Web reviews. The results section then describes the main themes identified in the concept map generated and provides examples of customer narratives for each theme. The last section presents the conclusions and theoretical and managerial implications, as well as the study's limitations and suggested avenues for future research.

\section{Literature Review}

\subsection{Service Quality}

Service quality has been a popular topic of debate in the literature on services (Ooi et al., 2011), and its conceptualisation, evaluation and measurement have received much scholarly attention (Abdullah et al., 2007). A consensus has been reached in the literature on marketing that superior service quality is a vital factor in companies' success in this era of intense competition and that service quality acts as an order winner in the marketplace (Singh and Sushil, 2013). Service quality is a major determinant of service-based companies' ability to enhance their perceived superiority and differentiation in increasingly competitive domestic and global markets (Zeithaml, 1988; Nam et al., 2011). Service quality thus helps companies to achieve genuine, sustainable competitive advantages (Sultan and Simpson, 2000).

Service quality can only be improved when it is regularly measured (Reichheld and Sasser, 1990), and the most accurate way to measure it is through consumers' eyes. 
Therefore, evaluating customers' expectations and adapting services to meet them is vital for companies' survival and customer retention (Ardakani et al., 2015). Securing customer satisfaction and loyalty through high-quality products and services is essential not only for long-term success but also for long-term survival (Reichheld and Sasser, 1990).

Service quality is defined as customers' opinion of the superiority or global excellence of a product or service (Zeithaml, 1988). Service quality can thus be broadly understood as meeting customers' expectations, requirements and satisfaction (Leong et al., 2015). The concept of service quality is widely regarded as a multidimensional construct, but the number of elements and their contents are still debated (Chao, 2008).

Early on, Parasuraman et al. (1985) defined service quality as the discrepancy between consumers' service expectations and their perceptions of the actual services provided. According to this disconfirmation paradigm, customers will perceive quality positively only when service providers meet or exceed the clients' expectations. In line with this definition, Zeithaml et al. (1996) posited that a good understanding of customers' expectations is important to delivering quality services. The most important model for measuring service quality based on this theory is Parasuraman et al.'s $(1985,1988)$ Service Quality (SERVQUAL) gap model, a 22-item instrument covering five key elements of service quality: tangibles, reliability, responsiveness, assurance and empathy (Parasuraman et al., 1988). This scale has received the most attention out of the various instruments proposed for measuring service quality (Ladhari, 2009). The instrument provides a comprehensive measurement scale for perceived service quality that has practical applications (Parasuraman et al., 1994).

Several studies have also confirmed the positive direct influence of customer satisfaction on consumers' behavioural intentions (e.g. Hui et al., 2007). Researchers have confirmed that service quality is strongly associated with repurchase intention (e.g. Ekiz and Arasli, 2007). Service quality also leads to positive word of mouth (WOM) (e.g. Cronin and Taylor, 1992; Shin and Elliott, 2001; Ekiz and Arasli, 2007), which provides organisations with a valuable form of indirect advertising (Park et al., 2005). Service quality also serves as an exit barrier, helping to retain customers (e.g. Amin et al., 2013) and securing brand loyalty (e.g. Chen, 2008).

\subsection{Service Quality in the Airline Industry}


A growing amount of research has focused on the relationship between service quality and customer satisfaction and loyalty in the airline industry (e.g. Ostrowski et al., 1993; Curry and Gao, 2012; Chen and Hu, 2013; Namukasa, 2013; Chow, 2014, 2015). Several studies have confirmed the antecedent role of service quality with respect to customer satisfaction in this industry (e.g. Han et al., 2008; Saha and Theingi, 2009; Archana and Subha, 2012; Namukasa, 2013; Leong et al., 2015; Hussain, 2016). The higher the perceived service quality, the more satisfied passengers are (Lau et al., 2011). The results reported in the previous literature also suggest that passenger satisfaction is an important driver of behavioural intentions among airline clients (Park et al., 2004, 2006; Clemes et al., 2008; Nadiri et al., 2008; Saha and Theingi, 2009; Leong et al., 2015; Singh, 2015; Hussain, 2016; Liu and Lee, 2016). In the airline industry, passenger satisfaction plays an important role in measurements of the quality of services and influences the likelihood consumers will maintain their relationships with service providers. This can take the form of not only repurchase intentions but also positive WOM (Cronin and Taylor, 1992; Abdullah et al., 2007; Saha and Theingi, 2009; Archana and Subha, 2012).

Researchers have also established that airline service quality is directly related to passenger loyalty and passengers' choice of airlines (Ostrowski et al., 1993; Taylor and Barker, 1994; Park et al., 2005, 2006; Chen, 2008; Jou et al., 2008; Chiou and Chen, 2012; Hussain, 2016). When passengers are satisfied, they tend to repurchase the airlines' services, which not only leads to increased brand loyalty but also to a reduction in the number of complaints (Chow, 2015). Airlines that provide better services than their competitors are able to build a solid foundation of customer loyalty (Curry and Gao, 2012).

\subsection{Value for Money in the Airline Industry}

Value for money can be defined as the trade-off between what consumers 'get' (i.e. benefits) and what these customers have to 'give up' (i.e. price) (Zeithaml, 1988). From the customers' perspective, airlines remain competitive if they deliver higher value for money than their main competitors do. Passengers flying on airlines that provide high value for money are expected to remain loyal and advocate that others use these 
companies (Messner, 2017). According to the literature on service, travel and tourism, value for money allows experts to predict overall customer satisfaction, loyalty, recommendation intentions and company profitability (Rajaguru, 2016).

Messner's (2017) study, for example, revealed a positive, extremely strong correlation between the perceived value for money shared online by airline passengers and their recommendation intentions. These results hold true both for economy and business class travellers. In addition, Rajaguru (2016) found that perceived value for money is a crucial factor for low-cost airlines' ability to achieve customer satisfaction and favourable behavioural intentions. In contrast, traditional full-service airlines survive on the balance between perceived value for money and service quality. Osaki and Kubota (2016) also found that customers pay more to receive higher process quality. More specifically, staff and premium service elements have a relatively strong influence on customer loyalty in the case of high value-added airlines.

\subsection{Service Attributes Relevant to Airline Service Quality}

The service sector depends on service quality, so measurements of service quality need to reflect service providers' operational circumstances (Liou et al., 2011) and the specific industry in question (Jiang and Zhang, 2016). Service quality in the airline industry is thus quite complex and differs from other industries (Feng and Jeng, 2005). This industry includes a chain of services, and service delivery can be divided not only into ground and inflight services (e.g. Chen and Chang, 2005; Li et al., 2017) but also into core and peripheral services (e.g. Ozment and Morash, 1994; Anderson et al., 2008). Airline service items are defined by the International Air Transportation Association, including reservation seating capacity, ticketing, check-in processes, inflight services, baggage handling and post-flight services (Feng and Jeng, 2005).

Prior research reported in the literature has identified determinants of airline service quality. These are, among others, air safety, baggage handling, on-time arrivals and departures, employee courtesy, airplane cleanliness, amenities, flight schedules and alternate flight arrangements for passengers who miss flights (e.g. Gardner, 2004; Gursoy et al., 2005; Pakdil and Aydin, 2007; Chau and Kao, 2009). Quite a few studies 
have investigated airline service dimensions that matter most to passengers including safety, frequency, punctuality, penalties for ticket changes, cabin services and inflight seat comfort (Gilbert and Wong, 2003; Chen and Chang, 2005; Liou and Tzeng, 2007; Liou et al., 2011; Martin et al., 2011).

Gilbert and Wong (2003), in turn, identified the most important airline service quality dimensions as reliability, assurance, facilities, employees, flight patterns, customisation and responsiveness. Park et al. (2005) assessed airline service quality using three dimensions, namely, inflight services, reliability and customer service, and convenience and accessibility. Pakdil and Aydin (2007) included multiple dimensions such as employees, tangibles, responsiveness, flight patterns, availability, image, and reliability and assurance.

The SERVQUAL scale has been widely used by scholars in the airline industry (e.g. Clifford et al., 1994; Sultan and Simpson, 2000; Chang and Yeh, 2002; Nejati et al., 2009). This scale has also been revised and adapted for this industry by other scholars (e.g. Tsaur et al., 2002; Gilbert and Wong, 2003; Park et al., 2005; Pakdil and Aydın, 2007; Hussain et al., 2015). These researchers have confirmed that the SERVQUAL scale provides general guidelines for service quality assessment in most service contexts, but scholars also suggest that the scale's factors ought to be examined and selected in light of industry-specific issues (Wu and Ko, 2013). In addition, Park et al. (2005) suggest that the airline industry has aspects of service quality (e.g. ticketing, baggage allowance and on-board facilities) that are different from those of other service industries and that are not considered in the SERVQUAL scale.

The Service Performance (SERVPERF) scale has been shown to be a better tool to measure service quality in the airline industry, but this alternative has also been criticised for assessing customer satisfaction only in relation to specific transactions (Ostrowski et al., 1993). Similarly to the SERVQUAL scale, SERVPERF has also been found to be too generic and unable to capture industry-specific dimensions of service quality in the airline sector (Cunningham et al., 2004).

In response to these issues, Nadiri et al. (2008) developed and validated the Airline Service Quality (AIRQUAL) scale, which comprises five distinct dimensions: airline tangibles, terminal tangibles, personnel, empathy and image. Wu and Cheng (2013) also found that their proposed assessment scale with four dimensions of service quality (i.e. 
interaction, physical environment, outcome and access) was psychometrically sound. However, the theoretical and conceptual basis for understanding the nature of passengers' perceptions of service quality in the airline industry is still in the developmental stage. Most measurement models are insufficiently comprehensive to capture accurately the service quality construct for this sector (Ali et al., 2015).

To fill this gap, many scholars have proposed multi-dimensional models of service quality specific to the airline industry. Gourdin (1988) categorised airline service quality into three criteria, namely, price, safety and timeliness. Developing a similar model, Ostrowski et al. (1993) used timeliness, food and beverage quality and seat comfort in order to evaluate airlines' service quality. Elliott and Roach (1993), in turn, considered flight timeliness, freight services, quality of food and beverage, seat comfort, ticket purchase processes and services offered before getting onboard to be the six main criteria for service quality evaluation of airline carriers. Truitt and Haynes (1994) used the check-in process, timeliness, seat cleanliness, food and beverage quality and customer complaint handling as dimensions of airline service quality. Yavari Gohar (2005) measured this industry's service quality based on flight safety, management, timeliness, frequency, inflight services and flight promotions. Saha and Theingi (2009) further assessed airline service quality using the dimensions of tangibles, schedules and services provided by ground staff and flight attendants.

In addition, Namukasa (2013) assessed airline service quality based on reliability, responsiveness and discounts (i.e. pre-flight service quality); tangibles, courtesy and language skills (i.e. inflight service quality); and frequent flyer programmes and timeliness (i.e. post-flight service quality). Wu and Cheng (2013) included a hierarchical structure, classifying airline service quality into four primary dimensions: interactions, physical environment, outcomes and access. The cited authors identified 11 sub-dimensions, namely, conduct, expertise, problem-solving, cleanliness, comfort, tangibles, safety and security, waiting time, valence, information and convenience. Li et al. (2017) measured inflight service quality in isolation by using items such as employees, facilities, flight schedule and information, supporting services and physical environment.

In view of the expanding literature on this topic, Lim and Tkaczynski (2017) conducted a comprehensive meta-analysis of 17 relevant studies published between 2003 and 2013 
and identified a total of 32 service-quality elements, some of which were more widely used than others. The most commonly used were employee appearance (15 studies), seating comfort (14 studies), meal service (14 studies), employee responsiveness (13 studies), inflight entertainment services (12 studies), baggage delivery (12 studies) and convenient flight schedule (12 studies).

\subsection{Role of Web reviews in service quality studies}

As mentioned previously, researchers have mainly used surveys to identify and validate the key dimensions of airline passengers' experiences. One exception is the research done by Liau and Tan (2014), who applied text mining techniques to analyse Twitter data and called for the use of this type of data in more studies. The cited authors concluded that the most frequent themes shared on Twitter about low-cost carriers are customer service, ticket promotions, flight cancelations and delays and post-booking management. These significant findings confirm that this field of research could benefit from studies of tourists and travellers' narratives in different social media platforms.

Recent studies have highlighted the role of content analysis of travellers' online reviews in service quality studies. Researchers have 'recognised [these reviews] as a natural setting for the study of travellers' lived experiences' (Zhang and Cole, 2016: 16). With the rise of Web 2.0 and social media platforms, customers can now easily leave their feedback online for everyone to see. Overall, Web reviews are perceived as accessible, reliable, credible and readily available information by both consumers and researchers (Lu and Stepchenkova, 2012). For managers, online reviews offer a budget- and timeefficient way to collect customer feedback (Zhang and Cole, 2016).

Researchers have previously analysed Web travel reviews in order to identify the main dimensions of consumers' overall experiences in various areas of the hospitality and tourism industry. For instance, Wu et al. (2014) studied shopping tourism in China. Pearce and $\mathrm{Wu}$ (2016) studied romantic tourism attractions in Australia. Zhang and Cole (2016) investigated lodging services for guests with mobility challenges. Rodrigues et al. (2017) focused on medical tourism, while Brochado et al. (2017) studied Airbnb in India, Portugal and the United States (US) and Lupu et al. (2017) investigated Bran Castle experiences in Romania. 


\section{Methodology}

\subsection{Data Collection}

The source for the Web reviews analysed in the present study was the TripAdvisor website, which is considered the largest online travel community in the world ( $\mathrm{Lu}$ and Stepchenkova, 2012). As in previous research using this type of data (Pearce and $\mathrm{Wu}$, 2016; Brochado et al., 2017; Lupu et al., 2017; Rodrigues et al., 2017), only English reviews were gathered for analysis.

The sample comprises 200 reviews of three companies from the two largest airline alliances - SkyTeam and Star Alliance (International Air Transport Association, 2016) - for a total of six companies and 1,200 reviews. The airlines selected from the SkyTeam were Air France, Delta Air Lines and Garuda Indonesia. The companies chosen from the Star Alliance were Air Canada, EVA Air and Lufthansa. Convenience sampling was employed to ensure the number of reviews needed to use Leximancer software, as well as to match the sample size of previous related studies. For instance, Pearce and $\mathrm{Wu}$ (2016) analysed 167 reviews, Rodrigues et al. (2017) used 603 reviews, Lupu et al. (2017) gathered 1,827 reviews and Brochado et al. (2017) collected 1,776 reviews.

Around $40 \%$ of the reviews were written by passengers from North America, $13.2 \%$ from Western Europe, 13.2\% from Far East Asia and 9.7\% from Oceania. In terms of gender, the sample is relatively equally distributed with $59.2 \%$ males and $40.8 \%$ females (see Table 1).

\section{Insert Table 1 here}

Table 2 summarises the descriptive statistics for the data on perceived service quality ratings. For all the items, the rating scale ranges from 1 to 5 . The variable with the highest and lowest ratings are cleanliness (4.06) and food and beverage (3.53), respectively.

Insert Table 2 here 


\subsection{Data Treatment}

Content analysis has gained increasing popularity as an effective method to interpret the fast-growing body of Web communications. Both qualitative and quantitative analyses can be used to process textual data (Zhang and Cole, 2016). Content analysis can thus be done with structured quantitative or unstructured qualitative methods. These involve, respectively, counting words or phrases and measuring observable text characteristics or making sense of what is written and extrapolating latent meanings from the data (Krippendorff, 2012). The mixed-method content analysis approach combines both types of methods to capture different, broader components of eWOM texts (Zhang and Cole, 2016).

The present study carried out quantitative content analyses of airline travellers' Web reviews using Leximancer, which transforms textual data from natural language into semantic patterns (Wu et al., 2014). Leximancer is a software programme that analyses the content of collections of textual documents and visually displays the extracted information. This software then graphically represents the main concepts contained within the texts and provides information about how the concepts are interrelated.

Leximancer follows quantitative procedures based on Bayesian statistical theory using algorithms and employing nonlinear dynamics and machine learning (Wu et al., 2014). The algorithms consider three main units: words, concepts and themes. This software uses a two-stage quantitative approach to extracting co-occurrence information in order to conduct both conceptual and relational analyses. Leximancer thus measures the presence of repeated concepts and the ways these concepts are semantically interrelated in order to produce a graphical representation of the results.

Since Leximancer conducts both conceptual and relational analyses, it measures not only the presence of defined concepts in the texts but also the ways the concepts are interrelated. The first step of the text analysis is the automatic identification of the words that most frequently appear in the texts. These words are the starting point for the definition of concepts, so the words are called 'concept seeds'. The objective of concept learning is to discover clusters of words that travel together throughout the texts in question and best represent concepts. These words are weighted according to their 
frequency of occurrence in sentences that include the concept compared with their frequency of occurrence elsewhere.

In addition, Leximancer also determines the frequency of co-occurrence between concepts. These frequencies are used to generate a visual representation called a 'concept map'. Those concepts that are placed near one another on the map appear frequently together in the same segments of text. Finally, the concepts are clustered into higher-level 'themes' with minimal manual intervention (Brochado et al., 2017). The themes aid further interpretation by grouping the concepts into clusters, which are shown as coloured circles on the map.

As in Brochado et al. (2017) and Lupu et al. (2017), the results of the present study's narrative (i.e. qualitative) analyses further indicate which source files (i.e. Web reviews) contain particular themes (Tkaczynski et al., 2015). This step adds greater depth of meaning to each theme. Leximancer's analyses also facilitate conceptual comparisons (i.e. highlighting divergence or nondivergence) between groups in the data defined by tags. In the present study, information regarding value for money ratings was included in the concept map as tags, grouping the themes into two categories: high (i.e. 4 and 5 out of 5 points) and low (i.e. 1 and 2 out of 5 points) ratings.

\section{Results}

\subsection{Overall Analysis}

The content analyses revealed the existence of nine themes in travellers' online descriptions of airline experiences: 'flights', 'seats', 'services', 'staff', 'airlines', '(ticket) classes', 'airports', 'entertainment' and 'fly(ing)'.

Insert Figure 1 here

\subsection{General Description of Airline Travel Experiences}

\subsubsection{Flights}

The theme of flights includes the concepts of 'flight' (count $=1,747$; relevance $=$ $100 \%)$, 'time' $(623,36 \%)$, 'plane' $(327,19 \%)$, 'check(-in)' $(187,11 \%)$ and 'return' 
$(156,9 \%)$. This first and most important dimension addresses the core services offered by airline companies during flights.

A typical review reads, '[I b]oarded on time but even with an hour delay [before takeoff], [the flight was] still on time. [The f]light was good, [and the] plane was [nice, with] a newer remodeled interior' (the US, male, Delta Air Lines). Another passenger shared, 'I originally booked the ticket because it was cheaper than other options, but [the airline] turned out to be great! Every flight I took with them was on time, [with] efficient boarding and disembarking' (Australia, male, Garuda Indonesia). A third passenger wrote, 'All flights were on time, [and] connected through Frankfurt outbound and Munich on return[;] both went smoothly' (the UK, male, Lufthansa).

\subsubsection{Seats}

The theme of seats includes the concepts of 'seat' (count $=650$, relevance $=37 \%$ ), 'comfort' (300, 17\%), 'leg' (204, 12\%), 'room' (204, 12\%) and 'trip' (211, 12\%). A passenger shared online:

This was our second leg in a Star Alliance Round the World ticket. It was an upgrade from Air Canada and Air China, [with] by far better check-in and inflight service. I fly to Europe once a year and I have never had so much legroom and fantastic service! Thank you[,] Air France! (the US, female, EVA Air) (emphasis in original)

Another passenger wrote, 'The aircraft was superb [an A330-200] with good legroom in economy class and the cabin crew were excellent! Everything was on time and went very smooth[ly]' (Indonesia, male, Garuda Indonesia). A third passenger wrote, 'Me and my wife [sic] flew with [A]ir Canada for our international flight to Tokyo. On the 787 Dreamliner there was lots of legroom' (Canada, male, Air Canada).

\subsubsection{Services}

The theme of services includes the concepts of 'service' (count $=712$, relevance $=$ $41 \%)$, 'food' (548, 30\%), 'customer' (172, 11\%) and '(beverages) served' $(166,10 \%)$. One passenger wrote, 'Even my granddaughter enjoyed the traditional food[;] a [sic] 
duck soup was her favourite. The seat ... turns into a comfortable bed, [and the] inflight entertainment, pajamas, [and] personal hygiene kit were all fabulous' (the UK, female, EVA Air). Another traveller reported, 'This is an excellent airline. The service is outstanding. From the food, the wine, chocolates [to the] juice, etc.[, i]t is just another kind of service. [I w]ill fly with them whenever I can' (Australia, male, Lufthansa). A further passenger stated:

[I received f]antastic customer service from all Air France staff. [This was a c]omfortable flight. [The airline h]as [a] drink/snack bar open during the entire flight ... not limited to water and juice like some other airlines. Menu cards are provided on each flight so you can easily make your meal choice in advance. [The f]ood was better than [what] most airlines [offer]. All alcohol was included, [with] no extra charges. [This is one of my] favorite airline[s]. (Canada, female, Air France)

\subsubsection{Staff}

The theme of staff comprises the concepts of 'staff' (count $=310$, relevance $=18 \%$ ), 'boarding' (274, 16\%), 'passenger' (272, 15\%), 'friendl(iness)' (172, 11\%), 'helpful(ness)' (136, 8\%) and 'nice (staff)' (151, 8\%). A typical opinion given regarding the staff is '[this was a] very pleasant experience. [The airline had h]elpful staff starting from check-in to landing' (Romania, female, Air France). Another passenger described her experience as follows:

[The staff were c]ourteous, [h]elpful and friendly. [They h]elped with [1]uggage and seating. I am a senior and they were very pleasant [and kind enough] to place me in a seat closer to the front of the plane. [I g]reatly appreciated [this]. [I t]ake trips three to four plus times a year to New York. It's very important to be [well] treated by Air Canada [s]taff to ease my trip. I ... travel alone. [I h]ave travelled [with] numerous Air Lines [sic] and have confidence ... [that] Air Canada ... [will] ensure a pleasant easy trip. (Canada, Female, Air Canada)

A third passenger shared, 'I was travelling on business ... . The airlines crew members were very polite ... [and I received] ... very nice, decent [sic] service' (India, male, Lufthansa). 


\subsubsection{Airlines}

The theme of airlines includes the concepts of 'airline' (337, 19\%) and 'experience' (232, 13\%). A typical review reads, '[I had a g]reat experience as always by [sic] Garuda Indonesia. ... They always know how to service [sic] their customer like a KING [sic]' (Indonesia, female, Garuda Indonesia). 'This was an exceptional overall experience in relation to all aspects of my flight from the beginning to the end[;] it felt like I was a VIP [very important person]!!!' (the UK, female, Air France). Another passenger wrote, 'I recently flew with EVA [Air] from BKK [Bangkok] to LHR [London Heathrow] to BKK. The flight on a B777-300ER was brilliant and certainly [a] $5[-]$ star experience' (Thailand, female, EVA Air).

\subsection{6 (Ticket) Classes}

The theme of (ticket) classes incudes the concepts of 'class' (339, 19\%), 'business' (320, 18\%), 'economy' $(231,13 \%)$ and 'flying' $(184,10 \%)$. This theme links airline companies with the main ticket classes they offer.

A passenger wrote, 'This was my first even [sic] flight with EVA A[ir]. I ... have [had] extensive experience [with] business class ... [on] Singapore Airlines. This is equal or even better than SQ [Singapore Airlines] service' (The Netherlands, female, EVA Air). Another passenger reported:

I traveled for the 1st time with Air France and [it] was a superb experience ... all ... because of the cabin crew they have. [The staff were v]ery helping [sic] and friendly and [there were] comfortable seats even in economy class. (India, female, Air France)

Another passenger shared:

Although it was economy class, ... I felt like ... [it was] business class. [The] 1[]hour trip was so amazing. We can [sic] order few [sic] types of drink, and also there was [a] snack with ...[some] of our traditional food. (Indonesia, male, Garuda Indonesia) 
An additional passenger wrote, 'My business class flights going both east and west were enjoyable' (the US, male, Delta Air Lines).

\subsubsection{Airports}

The theme of airports includes the concepts of 'airport' (195, 11\%), 'luggage' (251, $14 \%)$ and 'gate' $(119,7 \%)$. One review states:

Delta almost always demonstrates that it is a well[-]managed airline. We had timely announcements in the gate area, loaded on time, left on time, and arrived on time. ... [The] FAs [flight attendants] did a good job of stowing carry-on luggage and getting meal service out efficiently. ... AMS [Amsterdam Schiphol Airport] is a good airport experience both arriving in Europe and departing Europe. (the US, male, Delta Air Lines)

Still another review reads:

The Lufthansa Business Lounge at the Frankfurt [A]irport was excellent. [It has v]ery good and spacious shower cubicles with a lot of space, good lighting and good ventilation. [It offers a] well-equipped lounge with a good choice of food, snacks and nibbles and not too bad choice of drinks too. Also, [there are] computers, newspapers and so on if needed. The best part of the lounge was one does not feel ... [like one is in] a very busy airport for a few hours while waiting for a connecting flight. (Australia, male, Lufthansa)

One passenger shared, "[The airport offered e]xcellent service - on-line check-in, speedy bag drop at [the] airport, quick security and boarding, on[-]time take off, [and] very good inflight service. All in all [this was] a most efficient and helpful journey' (the US, male, Air France).

\subsubsection{Entertainment}

The theme of entertainment includes the concepts of 'entertainment' (185, 10\%), 'long (flight)' $(169,9 \%)$ and 'cabin' $(185,9 \%)$. This theme describes the variety of inflight entertainment available for all types of traveller (i.e. adults and kids). A passenger wrote: 
I was overall very pleased with this airline! ... On the way back from Mexico I was surprised to be on a plane that offered inflight entertainment with movies, games, flying updates, [and] live sports broadcasting, etc. on a personal monitor on the headrests of every seat. The airline even had free headphones for their travelers. (the US, female, Delta Air Lines)

Still another airline traveller said, 'The inflight entertainment was the best I'd every [sic] experienced. Plenty of movies, TV, podcasts and music ... help[ed] shorten the very lengthy flight' (the US, female, Air Canada). A further passenger reported, 'The entertainment system was really good, [with] a good range of movies and games ... They even had coloring books for the kids' (Australia, male, Garuda Indonesia).

\subsubsection{Fly(ing)}

The theme of fly(ing) $(184,10 \%)$ describes the post-purchase behavioural outcomes of the overall experience. A typical review states, 'I'd definitely fly [with] them again' (the UK, female, EVA Air). Another passenger wrote, 'I haven't flown with Garuda for many years[. W]ow have I missed out on something. The flight was fantastic. ... I was amazed and will definitely fly [with Garuda] again when I can' (Australia, female, Garuda Indonesia).

One traveller said, 'I have had some of the most pleasant experiences on Lufthansa flights and we are going to use them to fly to Romania this summer (the US, male, Lufthansa). An additional review states:

When I boarded my plane, there was soft, relaxing music playing. Immediately, the flight attendants attended to my needs. They were so professional and committed to excellent customer service. Wow, there were flowers in the restrooms along with lotions and facial mist. I was fed 3 meals along with countless beverages. The plane's interior was clean [and] like new[,] with pillows and blankets [and] with TV screens for each seat. The flight was smooth, left on time and arrived early. I will definitely fly [with] this airline again! (the US, female, EVA Air)

\subsection{Results of Value for Money Analysis}


The present study's second research objective was to determine whether tourists who evaluate their airline experiences as high (i.e. 4 or 5 out of 5 points) or low (i.e. 1 or 2 out of 5 points) value for money include different descriptions in narratives about their experiences and, thus, share different content in Web reviews. The results of the analysis show that airline passengers who give airlines a 4 ('Very good') or 5 ('Excellent') rating for the value for money item more frequently share narratives around the themes of seats, entertainment, services and staff. The most common concepts are related to tangibles, including seat ( $60 \%$ likelihood of co-occurrence), comfort (72\%) and legroom (57\%). The second most likely focus is linked with staff (71\%), which encompasses the concepts of helpful(ness) (70\%), friendl(iness) (64\%) and nice (staff) (59\%). Entertainment (66\%) is also an important theme for this segment of customers, as is services, which includes the concepts of food (59\%) and service $(58 \%)$.

In contrast, airline passengers that give airlines low value for money ratings (i.e. 1 or 2 out of 5 points) are more likely to share narratives about the core flight services and airport operations. An assessment of the concepts linked to this group's narratives revealed that the most frequently mentioned concepts are airport (39\%), luggage (39\%), gate (31\%), flight (27\%), time (38\%) and check(-in) (30\%) (see Table 3).

\section{Insert Table 3 here}

Examples of negative reviews about the airport theme focus mainly on incidents related to luggage that involved delays, losses, damages and a lack of effective help from the airline companies. One reviewer wrote:

Upon arrival we had to talk to the Delta desk to find [our] missing luggage. Then [we] told customs about the problem but [we received] no assistance getting through the long line!! [We a]rrived at [the] gate at 5 after the departure time [but the] plane is [sic] there but no personnel at [the] desk!! Now half our luggage is [sic] on one plane [and] half on another plane and hopefully we ... [would soon be] on a third plane!! (the US, male, Delta Air Lines)

A further unhappy traveller said:

[My 1]uggage was delayed by almost 3 days. However, that is NOT my complaint. My complaint with Air France is the way they handled the situation. 
How can an airline refuse to supply information to allow a person to follow up on the progress with [finding] his luggage and leave him [guessing] for almost 3 days ...? (South Africa, male, Air France)

Negative reviews linked with the flight theme were mainly due to incidents associated with delays. One such review reads:

[This is our f]irst and last time flying [with] Lufthansa. They did nothing right. Checking a bag took forever. [The f]light was late. They rebooked the connecting flight (also Lufthansa) without even giving us a chance to make the connection, despite still having half a[n] hour before it took off. (the US, male, Lufthansa)

Another disgruntled passenger wrote, 'My evening flight from London to Jakarta was cancelled due to a technical error[. U]nfortunately these things happen, but Garuda were not prepared for this at all' (the UK, male, Garuda).

\section{Discussion and Conclusion}

Even though customers are likely to be attracted by lower prices, service quality has consistently been identified as an important factor in customers' positive behavioural intentions such as loyalty and WOM (Liu and Lee, 2016; Li et al., 2017). Therefore, service quality is of the utmost importance to airlines seeking to thrive in a highly competitive market by attracting new customers and retaining existing ones (Hussain, 2016).

Given the increasing importance of user-generated content on the Internet in service quality studies (Lupu et al., 2017), the present research examined dominant themes in travellers' narratives shared online. An advantage of this type of study is the opportunity to target travellers from all over the world and to avoid the potential for biases associated with traditional surveys (Liau and Tan, 2014)

The current study sought to achieve two research objectives of which the first was to identify the main themes in descriptions of airline experiences shared online. Based on a sample of reviews of six airlines shared online, content analyses revealed nine themes in descriptions of airline travel experiences: flights, seats, services, staff, airlines, (ticket) classes, airports, entertainment and fly(ing). These themes were further grouped into 
core services during flights; airport operations; crew and ground staff; airline ticket classes; inflight tangibles such as seats, food and services, and entertainment; and postpurchase behaviours including continued patronage and recommendations.

The theme of flights is a dimension that covers the service quality element of airlines' core services identified by Lim and Tkaczynski (2017). This dimension mainly relates to overall travel experiences and flights' timeliness. Ardakani et al. (2015) concluded that timeliness is one of the most important criteria for airline passengers, and Min and Nin (2015) confirmed the importance of on-time arrivals and departures. In addition, flight cancellations and delays are one of the main topics discussed by consumers on Twitter (Liau and Tan, 2014) and thus an important driver of dissatisfaction.

Seats is an important dimension in the traveller narratives analysed in the present study, including many descriptions referring to legroom and comfort. According to the metaanalysis conducted by Lim and Tkaczynski (2017), seating comfort is among the most frequent items mentioned in airline service quality studies. The current results also confirm the relevance of the AIRQUAL scale developed by Ali et al. (2015), which includes airline tangibles as a dimension of airline experiences. Seating comfort is also an important dimension in Chen et al.'s (2008) research. Tangibles and physical elements are clearly an important dimension in previous studies (Namukasa, 2013; Wu and Cheng, 2013; Li et al., 2017). In addition, inflight services such as food and inflight entertainment rank among the most common themes in service quality studies, according to Lim and Tkaczynski (2017)

The airline on-board crew and ground staff are linked in the present study with concepts such as employee characteristics (e.g. friendly, nice and helpful). Employee service has also been included in previous service quality scales, such as Lim and Tkaczynski's (2017) study. Personnel and their empathy are dimensions of the AIRQUAL scale (Ali et al., 2015), while Saha and Theingi (2009) further distinguished between ground and inflight staff.

The airport dimension identified by the present research includes both airport tangibles and services (e.g. luggage, check-in and gate). Terminal tangibles is another AIRQUAL dimension (Ali et al., 2015). In addition, the role of proper baggage delivery was highlighted by Lim and Tkaczynski (2017). As reviews are shared in the post-purchase 
phase, passengers' narratives include overall assessments of airline experiences and intentions to fly again with the same company.

This paper offers valuable insights into how travellers perceived services provided by airline companies based on reviews these consumers share online. Leximancer's analytical tools facilitated the identification of the main themes in passengers' overall experiences, some of which proved to be more significant than other themes. In addition, this study's second research objective was to identify the main narrative themes aligned with higher and lower ratings of airlines' value for money. Content analyses revealed that these two passenger segments include different descriptions in their narratives about airline experiences, so the content shared online by the two segments contains contrasting themes.

These findings add to the existing literature (e.g., Rajaguru, 2016; Messner, 2017) by identifying service features linked with different value for money ratings. Airline passengers who evaluate airlines' value for money with high ratings (i.e. 4 or 5 out of 5 points) more frequently share narratives including the themes of seats, entertainment, services and staff. Airline passengers who give airlines low value for money ratings (i.e. 1 or 2 out of 5 points) are more likely to share their experiences of core inflight services (e.g. delays) and airport operations (e.g. lost, delayed or damaged luggage). Airline companies' failure to adopt a problem-solving approach is thus the primary source of negative reviews.

\section{Managerial Implications}

This study's results provide airline industry managers deeper insights into how travellers perceive airline service quality, as shown by their Web reviews. Understanding online reviews as a manifestation of passengers' experiences can help airlines to identify the main attributes required to achieve positive post-purchase behaviours and to minimise negative intentions. Therefore, travellers' reviews not only provide a cost-effective method for airline companies to collect feedback from their guests but also an opportunity to discover ways to generate positive post-purchase intentions. 
In order to generate high customer ratings and positive eWOM, airlines should both provide good core services (e.g. inflight services) and ensure service quality in ground services in the airports in which they operate. In addition, airplanes' tangibles (e.g. seating comfort) are quite frequently mentioned in passengers' narratives, so these features are a further way to improve passengers' experiences. Finally, inflight services (e.g. entertainment and food and beverage) are linked with the themes of staff and seats and are also important to customer satisfaction.

The present results indicate that customers who classify their trips' value for money as very good or excellent also provide positive eWOM about the airlines' seats, staff, entertainment and food. Passengers giving low value for money ratings write about negative experiences with airport operations and inflight services, which can arise from factors that cannot be controlled by the airlines (e.g. delays and third party ground operators). Therefore, airline companies need to acknowledge the number of negative incidents connected to these themes, identify the main causes and implement plans do minimise negative impacts on consumers' experiences. Showing passengers that airline staff are dedicated to solving problems is of the utmost importance.

\section{Limitations and Future Research}

This study has some limitations that need to be taken into consideration. First, only six airlines and 200 reviews per airline were included in this study. Further research could contribute to a fuller understanding of the main narratives in airline passengers' online reviews by comparing different types of airline companies (e.g. low-cost vs. full-service airlines) and including more companies in samples. Larger samples might allow future studies to test whether differences exist in the associations between value for money ratings and the main themes of travellers' overall airline experience for each company, as well as facilitating comparisons between airlines' market positioning.

Second, the present research only focused in one social media platform. Further studies could compare user-generated content from different social media (e.g. Facebook, Twitter and Instagram) to assess congruence with this research's findings. Another issue that merits more study is to test whether the main themes of passengers' overall experiences vary according to traveller profiles (e.g. gender, nationality or business vs. 
economic class). This may provide more insights regarding market segmentation in the airline industry. Future studies could also use other qualitative methods to add more depth to the present findings on airline travellers' perspectives.

\section{References}

Abdullah, K., Manaf, N.H.A. and Noor, K.M. (2007), "Measuring the service quality of airline services in Malaysia", IIUM Journal of Economics and Management, Vol. 15 No. 1, pp. 1-29.

Ali, F., Dey, B. L. and Filieri, R. (2015), “An assessment of service quality and resulting customer satisfaction in Pakistan International Airlines", International Journal of Quality \& Reliability Management, Vol. 32 No. 5, pp. 486-502.

Amin, M., Yahya, Z., Ismayatim, W.F.A., Nasharuddin, S.Z. and Kassim, E. (2013), "Service quality dimension and customer satisfaction: an empirical study in the Malaysian hotel industry”, Services Marketing Quarterly, Vol. 34 No. 2, pp. 115-25. Anderson, S., Pearo, L.K. and Widener, S.K. (2008), "Drivers of service satisfaction: linking customer satisfaction to the service concept and customer", Journal of Service Research, Vol. 10 No. 4, pp. 365-81.

Archana, R. and Subha, M.V. (2012), “A study on service quality and passenger satisfaction on Indian Airlines", International Journal of Multidisciplinary Research, Vol. 2 No. 2, pp. 50-63.

Ardakani, S.S., Nejatian, M., Farhangnejad, M.A. and Nejati, M. (2015), “A fuzzy approach to service quality diagnosis", Marketing Intelligence \& Planning, Vol. 33 No. 1, pp. 103-19.

Atalik, O., Kampüsü, I.E. and Turkey, E. (2009), “A study to determine the effects of customer value on customer loyalty in airline companies operating: case of Turkish air travelers", International Journal of Business and Management, Vol. 4 No. 6, pp. 15462.

Berry, L.L., Zeithaml, V.A. and Parasuraman, A. (1985), "Quality counts in services, too", Business Horizons, Vol. 28 No. 3, pp. 44-52. 
Brochado, A., Troilo, M. and Shah, A. (2017), "Airbnb customer experience: evidence of convergence across three countries", Annals of Tourism Research, Vol. 63, pp. 21012.

Chang, Y. and Yeh, C. (2002), "A survey analysis of service quality for domestic airlines", European Journal of Operational Research, Vol. 139 No. 1, pp. 166-77.

Chao, P. (2008), "Exploring the nature of the relationships between service quality and customer loyalty: an attribute level analysis”, The Service Industries Journal, Vol. 28 No. 2, pp. 95-116.

Chau, V.S. and Kao, Y.-Y. (2009), "Bridge over troubled water or long and winding road? Gap-5 in airline service quality performance measures", Managing Service Quality, Vol. 19 No. 1, pp. 106-34.

Chen, A.H., Peng, N. and Hackley, C. (2008), "Evaluating service marketing in the airline industry and its influence on student passengers' purchasing behavior using the Taipei-London Route as an example", Journal of Travel \& Tourism Marketing, Vol. 25 No. 2, pp. 149-60.

Chen, C.F. (2008), "Investigating the structural relationships between service quality, perceived value, satisfaction, and behavioral intentions for air passengers: evidence from Taiwan", Transportation Research Part A, Vol. 42 No. 4, pp. 709-17.

Chen, F.Y. and Chang, Y.H. (2005)," Examining airline service quality from a process perspective", Journal of Air Transport Management, Vol. 11 No. 2, pp. 166-77.

Chen, P.T. and Hu, H.H.S. (2013), "The mediating role of relational benefit between service quality and customer loyalty in airline industry", Total Quality Management and Business Excellence, Vol. 24 No. 9, pp. 1084-95.

Chiou, Y. and Chen, Y. (2012), "Service quality effects on air passenger intentions: a service chain perspective", Transportmetrica, Vol. 8 No. 6, pp. 406-26.

Chow, C.K.W. (2014), "Customer satisfaction and service quality in the Chinese airline industry", Journal of Air Transport Management, Vol. 35, pp. 102-7.

Chow, C.K.W. (2015), "On-time performance, passenger expectations and satisfaction in the Chinese airline industry", Journal of Air Transport Management, Vol. 47, pp. 3947. 
Clemes, M.D., Gan, C., Kao, T.H. and Choong, M. (2008), “An empirical analysis of customer satisfaction in international air travel”, Innovative Marketing, Vol. 4 No. 2 , pp. 49-62.

Clifford, Y., Cunningham, L. and Moomkyu, L. (1994), "Assessing service quality as an effective management tool: the case of the airline industry", Journal of Marketing Theory and Practice, Vol. Spring, pp. 76-96.

Cronin, J. and Taylor, S.A. (1992), "Measuring service quality: a re-examination and extension”, Journal of Marketing, Vol. 56, pp. 55-67.

Cunningham, L.F., Young, C.E. and Lee, M. (2004), "Perceptions of airline service quality pre and post 9/11”, Public Works Management \& Policy, Vol. 9 No. 1, pp. 1025.

Curry, N. and Gao, Y. (2012), "Low-cost airlines: a new customer relationship? An analysis of service quality, service satisfaction and customer loyalty in a low-cost setting”, Services Marketing Quarterly, Vol. 33 No. 2, pp. 104-18.

Ekiz, H.E. and Arasli, H. (2007), "Measuring the impacts of organizational responses: case of Northern Cyprus hotels", Managing Global Transitions: International Research Journal, Vol. 5 No. 3, pp. 271-87.

Elliott, K. and Roach, D.W. (1993), "Service quality in the airline industry: are carriers getting an unbiased evaluation from consumers?", Journal of Professional Service Marketing, Vol. 9 No. 2, pp. 71-82.

Feng, C.-M. and Jeng, K.-Y. (2005), “Analyzing airline service improvement strategy through importance and performance analysis", Journal of the Eastern Asia Society for Transportation Studies, Vol. 6, pp. 782-97.

Frost, F.A. and Kumar, M. (2000), "INTSERVQUAL - an internal adaptation of the GAP model in a large service organisation", Journal of Services Marketing, Vol. 14 No. 5, pp. 358-77.

Gardner, E.S. Jr. (2004), “Dimensional analysis of airline quality”, Interfaces, Vol. 34 No. 4, pp. 272-9.

Gilbert, D. and Wong, R.K. (2003), "Passenger expectations and airline services: a Hong Kong based study”, Tourism Management, Vol. 24 No. 5, pp. 519-32. 
Gourdin, K. (1988), "Bringing quality back to commercial travel", Transportation Journal, Vol. 27 No. 3, pp. 23-9.

Gourdin, K.N. and Kloppenbourg, T.J. (1991), "Identifying service gaps in commercial air travel: the first step toward quality improvement", Transportation Journal, Vol. Fall, pp. 22-30.

Gursoy, D., Chen, M.-H. and Kim, H.-J. (2005), "The US airlines relative positioning based on attributes of service quality”, Tourism Management, Vol. 26 No. 1, pp. 57-67. Han, X., Kwortnik, R. and Wang, C. (2008), "Service loyalty: an integrated model and examination across service contexts", Journal of Service Research, Vol. 11 No. 1, pp. $22-42$.

Hui, T.K., Wan, D. and Ho, A. (2007), “Tourists' satisfaction, recommendation and revisiting: Singapore”, Tourism Management, Vol. 28, pp. 965-75.

Hussain, R. (2016), “The mediating role of customer satisfaction: evidence from the airline industry", Asia Pacific Journal of Marketing and Logistics, Vol. 28 No. 2, pp. 234-55.

Hussain, R., Nasser, A.A. and Hussain, Y.K. (2015), "Service quality and customer satisfaction of a UAE-based airline: an empirical investigation", Journal of Air Transport Management, Vol. 42, pp. 167-75.

International Air Transport Association (2016), "Sixtieth world air transport statistics", available at: . http://www.iata.org/pressroom/pr/Pages/2016-07-05-01.aspx (accessed 15 February 2018).

Jiang, H. and Zhang, Y. (2016), “An investigation of service quality, customer satisfaction and loyalty in China's airline market", Journal of Air Transport Management, Vol. 57, pp. 80-8.

Jou, R., Lam, S., Hensher, D., Chen, C. and Kuo, C. (2008), "The effect of service quality and price on international airline competition", Transportation Research Part E: Logistics and Transportation Review, Vol. 44 No. 4, pp. 580-92.

Krippendorff, K. (2012), Content Analysis: An Introduction to Its Methodology, Sage Publications, Inc, Thousand Oaks, CA. 
Ladhari, R. (2009), “A review of twenty years of SERVQUAL research”, International Journal of Quality and Service Sciences, Vol. 1 No. 2, pp. 172-98.

Lau, T.C., Kwek, C.L. and Tan, H.P. (2011), “Airline e-ticketing service: how e-service quality and customer satisfaction impacted purchase intentions", International Business Management, Vol. 5 No. 4, pp. 200-8.

Leong, L.Y., Hew, T.S., Lee, V.H. and Ooi, K.B. (2015), “An SEM -artificial-neuralnetwork analysis of the relationships between SERVPERF, customer satisfaction and loyalty among low-cost and full-service airlines", Expert Systems with Applications, Vol. 42 No. 19, pp. 6620-34.

Li, W., Yu, S., Pei, H., Zhao, C. and Tian, B. (2017), “A hybrid approach based on fuzzy AHP and 2-tuple fuzzy linguistic method for evaluation in-flight service quality", Journal of Air Transport Management, Vol. 60, pp. 49-64.

Liau, B.Y. and Tan, P.P. (2014), "Gaining customer knowledge in low cost airlines through text mining", Industrial Management \& Data Systems, Vol. 114 No. 9, pp.1344-59.

Lim, S.S. and Tkaczynski, A. (2017), "Origin and money matter: the airline service quality expectations of international students", Journal of Hospitality and Tourism Management, Vol. 31, pp. 244-52.

Liou, J.J.H., Hsu, C.C., Yeh, W.C. and Lin, R.H. (2011), "Using a modified grey relation method for improving airline service quality”, Tourism Management, Vol. 32 No. 6, pp. 1381-8.

Liou, J.J.H. and Tzeng, G.H. (2007), “A non-additive model for evaluating airline service quality", Journal of Air Transport Management, Vol. 13 No. 3, pp. 131-8. Liu, C.-H.S. and Lee, T. (2016), "Service quality and price perception of service: influence on word-of-mouth and revisit intention", Journal of Air Transport Management, Vol. 52, pp. 42-54.

Lu, W. and Stepchenkova, S. (2012), "Ecotourism experiences reported online: classification of satisfaction attributes", Tourism Management, Vol. 33 No. 3, pp. $702-$ 12. 
Lupu, C., Brochado, A. and Stoleriu, O.M. (2017), "Experiencing Dracula's homeland”, Tourism Geographies, Vol. June, available at: http://dx.doi.org/10.1080/14616688.2017.1336786 (accessed 15 July 2017).

Martin, J.C., Roman, C. and Espino, R. (2011), "Evaluating frequent flyer programs from the air passengers' perspective", Journal of Air Transport Management, Vol. 17, pp. 364-8.

Messner, W. (2017), "Does value for money create advocates? A study in the international airline services industry", Journal of Global Marketing, Vol. 30 No. 5, pp. $309-21$.

Min, H. and Min, H. (2015), "Benchmarking the service quality of airlines in the United States: an exploratory analysis", Benchmarking: An International Journal, Vol. 22 No. 5, pp. 734-51.

Nadiri, H., Hussain, K., Ekiz, E.H. and Erdoğan, S. (2008), “An investigation on the factors influencing passengers' loyalty in the north Cyprus National Airline", The TQM Journal, Vol. 20 No. 3, pp. 265-80.

Nam, J., Ekinci, Y. and Whyatt, G. (2011), "Brand equity, brand loyalty and consumer satisfaction”, Annals of Tourism Research, Vol. 38 No. 3, pp. 1009-30.

Namukasa, J. (2013), "The influence of airline service quality on passenger satisfaction and loyalty: the case of Uganda airline industry", The TQM Journal, Vol. 25 No. 5, pp. $520-32$.

Nejati, M., Nejati, M. and Shafaei, A. (2009), “Ranking airlines' service quality factors using a fuzzy approach: study of the Iranian society". International Journal of Quality and Reliability Management, Vol. 26 No. 3, pp. 247-60.

O’Connell, J.F. and Williams, G. (2005), “Passengers' perceptions of low cost airlines and full service carriers: a case study involving Ryanair, Aer Lingus, Air Asia and Malaysia Airlines", Journal of Air Transport Management, Vol. 11 No. 4, pp. 259-72. Ooi, K. B., Lin, B., Tan, B.I. and Chong, A.Y.L. (2011), “Are TQM practices supporting customer satisfaction and service quality?", Journal of Services Marketing, Vol. 25 No. 6, pp. 410-9. 
Osaki, T. and Kubota, Y. (2016), "Perceptions of premium service and superiority: why do customers pay more for high-value-added domestic airline services in Japan?", Journal of Air Transport Management, Vol. 57, pp. 196-201.

Ostrowski, P.L., O’Brien, T. and Gordon, G. (1993), "Service quality and customer loyalty in the commercial airline industry", Journal of Travel Research, Vol. 32, pp. 1624.

Ozment, J. and Morash, E.A. (1994), “The augmented service offering for perceived and actual service quality", Journal of the Academy of Marketing Science, Vol. 22 No. 4, pp. 352-63.

Pakdil, F. and Aydın, O. (2007), "Expectations and perceptions in airline services: an analysis using weighted SERVQUAL scores", Journal of Air Transport Management, Vol. 13 No. 4, pp. 229-37.

Parasuraman, A., Zeithaml, V.A. and Berry, L.L. (1988), "SERVQUAL: a multipleitem scale for measuring consumer perceptions of service quality", Journal of Retailing, Vol. 64 No. 1, pp. 12-40.

Parasuraman, A., Zeithaml, V.A. and Berry, L.L. (1994), "Alternative scales for measuring service quality: a comparative assessment based on psychometric and diagnostic criteria", Journal of Retailing, Vol. 70 No. 3, pp. 201-29.

Park, J.W., Robertson, R. and Wu, C.L. (2004), "The effect of airline service quality on passengers' behavioral intentions: a Korean case study", Journal of Air Transport, Vol. 10 No. 6, pp. 435-9.

Park, J.W., Robertson, R. and Wu, C.L. (2005), "Investigating the effects of airline service quality on airline image and passengers' future behavioural intention: findings from Australian international air passengers", The Journal of Tourism Studies, Vol. 16 No. 1, pp. 2-11.

Park, J.W., Robertson, R. and Wu, C.L. (2006), "Modelling the impact of airline service quality and marketing variables on passengers' future behavioural intentions", Transportation Planning and Technology, Vol. 29 No. 5, pp. 359-81. 
Pearce, P. and Wu, M.Y. (2016), "Tourists' evaluation of a romantic themed attraction: expressive and instrumental issues", Journal of Travel Research, Vol. 55 No. 2, pp. $220-32$.

Rajaguru, R. (2016), "Role of value for money and service quality on behavioural intention: a study of full service and low cost Airlines", Journal of Air Transport Management, Vol. 53, pp. 114-22.

Reichheld, F.F. and Sasser, W.E. Jr. (1990), “Zero defections: quality comes to services", Harvard Business Review, Vol. 68, pp. 105-11.

Rodrigues, H., Brochado, A., Troilo, M. and Mohsin, A. (2017), "Mirror, mirror on thewall, who's the fairest of them all? A critical content analysis on medical tourism", Tourism Management Perspectives, Vol. 24, pp. 16-25.

Saha, G.C. and Theingi (2009), "Service quality, satisfaction, and behavioural intentions: a study of low-cost airline carriers in Thailand", Managing Service Quality, Vol. 19 No. 3, pp. 350-72.

Shaw, S. (1999), Airline Marketing and Management, Ashgate, Hampshire, UK.

Shin, D. and Elliott, K. (2001), "Measuring customers' overall satisfaction: a multiattributes assessment”, Services Marketing Quarterly, Vol. 22 No. 1, pp. 3-20.

Singh, A.K. (2015), "Modeling passengers' future behavioral intentions in airline industry using SEM", Journal of Advances in Management Research, Vol. 12 No. 2, pp. $107-27$.

Singh, A.K. and Sushil (2013), "Modeling enablers of TQM to improve airline performance", International Journal of Productivity and Performance Management, Vol. 63 No. 3, pp. 250-75.

Sultan, F. and Simpson, M.C., Jr. (2000), "International service variants: airline passenger expectations and perceptions of service quality", Journal of Services Marketing, Vol. 14 No. 3, pp. 188-216.

Taylor, S.A. and Barker, T.L. (1994), “An assessment of the relationship between service quality and customer satisfaction in the formation of consumer's purchase intentions", Journal of Retailing, Vol. 72 No. 2, pp. 163-78. 
Tiernan, S., Rhoades, D. and Waguespack, B. (2008), “Airline service quality: exploratory analysis of consumer perceptions and operational performance in the USA and EU”, Managing Service Quality, Vol. 18 No. 3, pp. 212-24.

Truitt, L. and Haynes, R. (1994), "Evaluating service quality and productivity in the regional airline industry", Transportation Journal, Vol. 33 No. 4, pp. 21-32.

Tsaur, S.H., Chang, T.Y. and Yen, C.H. (2002), "The evaluation of airline service quality by fuzzy MCDM”, Tourism Management, Vol. 23 No. 2, pp. 107-15.

Wu, H.-C. and Cheng, C.C. (2013), "A hierarchical model of service quality in the airline industry", Journal of Hospitality and Tourism Management, Vol. 20, pp. 13-22. Wu, H.C. and Ko, Y.J. (2013), "Assessment of service quality in the hotel industry", Journal of Quality Assurance in Hospitality \& Tourism, Vol. 14 No. 3, pp. 218-44. Wu, M.-Y., Wall, G. and Pearce, P.L. (2014), "Shopping experiences: international tourists in Beijing's Silk Market”, Tourism Management, Vol. 41, pp. 96-106.

Yavari Gohar, F. (2005), “Affecting factors on perception of local consumers in selecting airlines", Journal of Management Studies, Vol. 13 No. 4-5, pp. 79-112. Young, C., Lawrence, C. and Lee, M. (1994), "Assessing service quality as an effective management tool: the case for the airline industry", Journal of Marketing Theory and Practice, Vol. 2 No. 2, pp. 76-96.

Zeithaml, V.A. (1988), "Consumer perceptions of price, quality, and value: a means-end and synthesis of evidence", Journal of Marketing, Vol. 52 No. 3, pp. 2-22.

Zeithaml, V.A., Berry, L.L. and Parasuraman, A. (1996), "The behavioral consequences of service quality", Journal of Marketing, Vol. 60 No. 2, pp. 31-46.

Zhang, Y. and Cole, S.T. (2016), "Dimensions of lodging guest satisfaction among guests with mobility challenges: a mixed-method analysis of web-based texts", Tourism Management, Vol. 53, pp. 13-27. 
Table 1: Descriptive statistics for reviewers $($ number $=1200)$

\begin{tabular}{llrr}
\hline \multirow{2}{*}{ Variable } & \multicolumn{1}{c}{ Category } & & \multicolumn{1}{c}{$\%$} \\
\hline \multirow{4}{*}{ Origin } & Africa & 16 & $1.5 \%$ \\
& Central Asia & 21 & $1.9 \%$ \\
& Eastern Europe & 29 & $2.7 \%$ \\
& Eurasia \& Middle & & \\
& East & 7 & $0.6 \%$ \\
& Far East Asia & 144 & $13.2 \%$ \\
& Latin America & 27 & $2.5 \%$ \\
& North America & 436 & $40.0 \%$ \\
Gender & Oceania & 106 & $9.7 \%$ \\
& Western Europe & 304 & $27.9 \%$ \\
\hline \multirow{2}{*}{} & F & 490 & $40.8 \%$ \\
& M & 710 & $59.2 \%$ \\
\hline
\end{tabular}


Table 2: Descriptive statistics for service quality ratings

\begin{tabular}{lccccc}
\hline \multicolumn{1}{c}{ Variable } & Average & Median & SD & Min & Max \\
\hline Cleanliness & 4.06 & 4 & 1.02 & 1 & 5 \\
Check-in and Boarding & 3.86 & 4 & 1.31 & 1 & 5 \\
Customer Service & 3.78 & 4 & 1.43 & 1 & 5 \\
Legroom & 3.66 & 4 & 1.17 & 1 & 5 \\
Seat Comfort & 3.63 & 4 & 1.15 & 1 & 5 \\
Value for Money & 3.58 & 4 & 1.32 & 1 & 5 \\
Inflight Entertainment & & & & & \\
(Wi-Fi, Television, & 3.54 & 4 & 1.32 & 1 & 5 \\
Movies) & & & & & \\
Food and Beverage & 3.53 & 4 & 1.30 & 1 & 5 \\
\hline
\end{tabular}

Notes: $\mathrm{SD}=$ standard deviation; $\min =$ minimum; $\max =$ maximum 
Table 3: Main themes and concepts by value for money ratings

\begin{tabular}{|l|l|l|}
\hline \multicolumn{1}{|c|}{$\begin{array}{c}\text { Value for Money } \\
\text { Rating }\end{array}$} & \multicolumn{1}{|c|}{ Theme } & \multicolumn{1}{|c|}{ Concepts } \\
\hline \multirow{3}{*}{ Low (1 or 2 points) } & Flight (services) & $\begin{array}{l}\text { Time (38\% likelihood), check(-in) (30\%), } \\
\text { flight (27\%), return (27\%), plane (22\%) }\end{array}$ \\
\cline { 2 - 3 } & Airport & Airport (39\%), luggage (39\%), gate (31\%) \\
\hline \multirow{3}{*}{ High (4 or 5 points) } & Seats & $\begin{array}{l}\text { Comfortable (72\%), seat (60\%), leg (57\%), } \\
\text { room (57\%), trip (50\%) }\end{array}$ \\
\cline { 2 - 4 } & Entertainment & $\begin{array}{l}\text { Entertainment (66\%), (flight) log (54\%), cabin } \\
(54 \%)\end{array}$ \\
\cline { 2 - 3 } & Services & $\begin{array}{l}\text { Food (59\%), service (58\%), customer (34\%), } \\
\text { beverages (served) (30\%) }\end{array}$ \\
\cline { 2 - 4 } & Staff & $\begin{array}{l}\text { Staff (71\%), helpfulness (70\%), friendl(iness) } \\
(64 \%), \text { nice (staff) (59\%), boarding (process) } \\
(46 \%), \text { passenger (36\%) }\end{array}$ \\
\hline
\end{tabular}




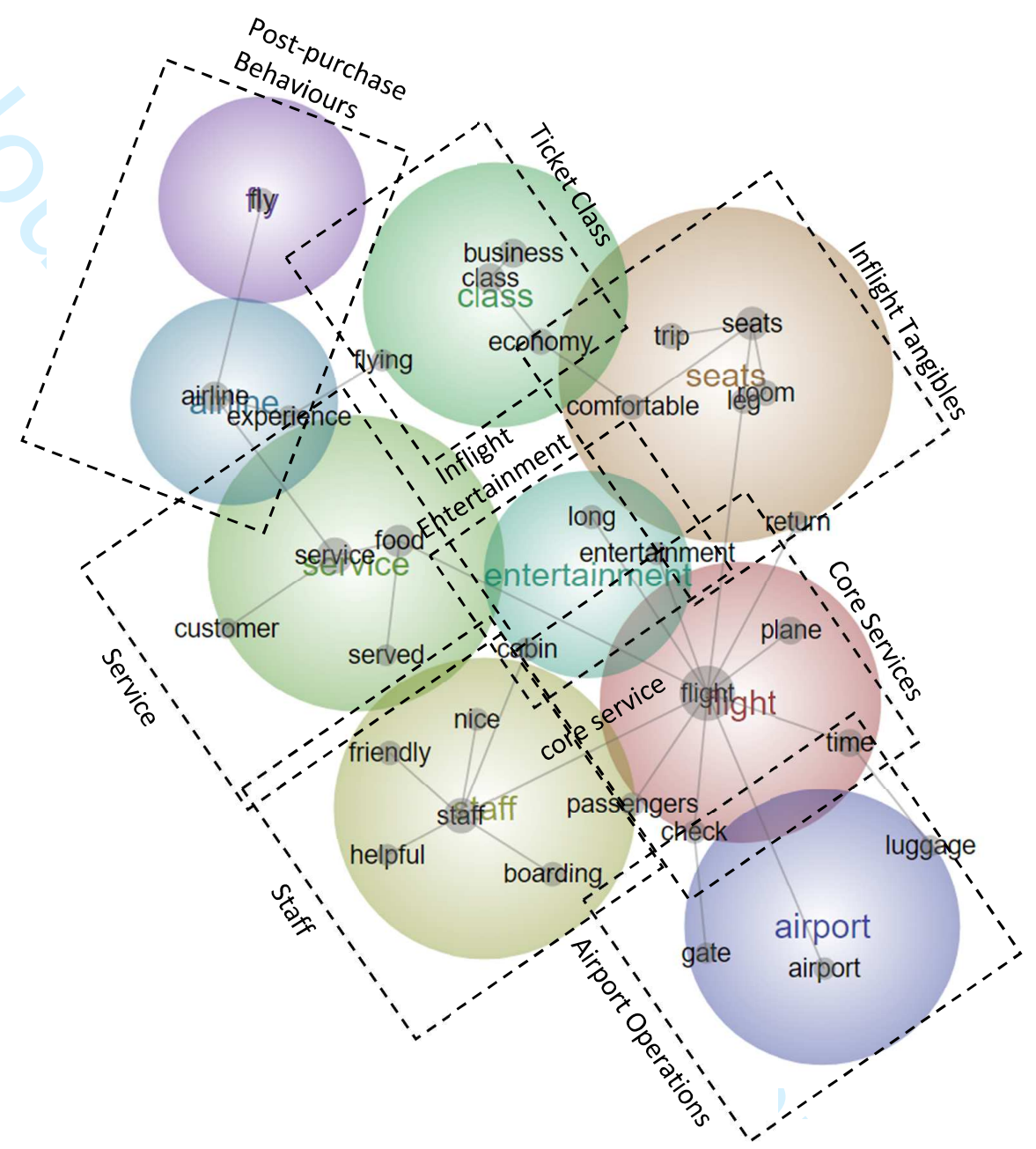

Figure 1: Concept map 